\title{
Bpmn in Health Institutions- A Study of the Importance of Process Modelling In This Sector
}

\author{
Bruna Luciano \\ Superior Management School of Idanha-a-Nova \\ Polytechnic Institute of Castelo Branco, Portugal \\ bruna.s.luciano@gmail.com
}

\begin{abstract}
Currently, a healthcare institution, of whatever type, needs a detailed management of all the processes involved, so that these organizations and their professionals can provide their services more efficiently, and archive the goals of the institution.

In health institutions, the processes aren't identified, procedure's manuals are difficult to interpret and often, the professionals don't have time to consult them. Business Process Management can be a possible solution, used for managing the processes in this type of institution, decreasing human and technical errors.

This article aims to study the importance and the need to implement the Business Process Modelling and Notation (BPMN) in a healthcare institution, through the analysis of statistical data from the application of an inquiry to the different kind of professionals who exercise their daily activities in these organizations, evaluating their knowledge about the processes in their institution and service, and how easy they can consult procedure's manuals in case of doubt.
\end{abstract}

Being this a notation used in the business and management fields, the literature and studies realised are few, when we corelate BPMN and the health field.

Although only $20,6 \%$ of the professionals inquired know this notation, $72,2 \%$ thinks that the implementation of a method that defines and characterises the processes performed in the service and institution where they work, is advantageous. In addition to that, when we analyse the answers given by the professionals, about the trust, easiness, and quickness with what they consult the procedure's manuals, the means were relatively low.

Keywords: Business Process Management; BPMN; Health Institution; Processes. 


\section{Introduction}

Organizations have activities that interrelate and that in certain ways, deliver products or services. All products or services provided by an organization are the result of a set of processes that aim to achieve the organization's goals (Junior, Rocha, \& Cunha, 2013).

A process is a series of activities carried out within a company or organization. One process model defines the behaviour of a process and consists of a clear start, various tasks that need to be performed, sequences and conditions that determine the flow, and a clear end (Stemerding \& Dijk, 2005).

Currently, in several health units, the processes carried out daily in the various services are not clearly identified and formalized. In order to clarify and thoroughly manage these same processes, the areas of health and management were united and considered a solution to simplify the work of various professionals, so that themselves are constantly willing and prepared to render their service.

Business Process Management (BPM) is a discipline whose purpose is to improve in an organization's business processes, in order to make the work more quickly and effectively, and consequently, simplifying processes, reducing the use of resources, and significantly improving the precision with which the work is drawn. BPM is even able to provide documentation and process data in real time, which is essential in the services of an organization in the health area (Gomes, 2018).

Organizations that adopt the practice of process-oriented management require that they are previously modelled in a specific language. There are several languages of process modeling, and this study will be addressed in a more deepens the BPMN (Business Process Modeling Notation), which allows organizations obtain graphical representations of their processes, perceive anomalies, inconsistencies, and inefficiencies in their processes, through diagrams (Freitas, 2015).

The objective of this work focuses on the study of the perception of the need for application of the organizational practice of process-oriented management, in a healthcare institution, through the analysis of the responses of various professionals, to a questionnaire, which exercise their function in organizations of this type.

The article will be divided into several chapters, including the literature review (which includes the business process management and the modeling and notation of these same processes), and methodology used (addressing the characterization of the questionnaire, data collection and processing). Later, the results chapter will be presented, with all the characterization of the sample and the results from the questionnaire applied, and finally the conclusion.

\section{Literature Review}

\section{Business Process Management}

Organizations can keep a special focus on their business processes, which is known as BPM (Business Process Management). This management process-oriented business offers 
MANAGEMENT, ECONOMICS AND HUMANITIES

July 23-25 2021

Stockholm, Sweden

organizations increased levels of performance and superior flexibility to functional and hierarchical management. With the adoption of process-oriented management business organizations have more capabilities to respond to the needs and changes of the market efficiently and effectively (Rolón, Chavira, Orozco, \& Soto, 2015).

According to Gomes (2018), the foundations of an organization are its business processes and the how they are managed. A better management of your business processes is equivalent to an organization more capable of achieving its goals, with BPM being a key part of success current status of an organization. It makes the organization have a clear view of its processes and relationships with each other in order to successfully execute their products and services.

On the other hand, for Lee \& Dale (1998), BPM is a structured and systematic approach which aims to analyse, improve, control, and manage business processes in order to increase the quality of products and services, facilitating the creation of value, as well as analysing and improving core activities such as production, marketing, communications, and other fundamental elements of the company on an ongoing basis.

Research in the area of Business Process Management was developed gradually as a "discipline" aimed at computer science, management, the business sector, and information systems (Fernández, Fernandéz, \& García, 2019), being recognized and respected by professionals, due to the academic impact it had. In recent decades, according to van der Aalst, ter Hofstede, and Weske (2003), there has been a growing interest in Process Management. Business due to its contribution to increased productivity, achievement of operational excellence or cost savings.

BPM notations are intended to represent how processes occur in organizations, thus as the interaction between the participants and the execution of activities, which follow a set of rules in order to achieve a goal. There are different types of notation/language (Silva \& Soares, 2016), such as the Integrated Definition Language (IDEF 0, IDEF3) (Kim, Dong-Soon Yim, \& Weston, 2001), Unified Modeling Language (UML), UML2.0 (Siau, 2010), and the BPMN. Next, we will discuss this last type of notation.

\subsection{Modelling and notation in business processes}

BPMN was developed by the Business Process Management Initiative (BPMI) and went through a series of revisions. In 2005, BPMI joined the Object Management Group (OMG), which took the initiative, and launched in 2011 BPMN 2.0, changing the name of the notation to Business Process Model and Notation. A more detailed pattern for modeling has been developed of business processes, using a richer set of symbols and notations for diagrams processes (Lucis Software Inc., 2020; Silva \& Soares, 2016).

This is a language designed specifically for business process modeling, 34 at an organizational level, and achieved a high degree of general acceptance in the business fabric due to the fact that it was developed to be used and understood by any type of professional, regardless of their training or role in an organization (Directors, Analysts, Technicians, Engineers, among others), without the need for technical knowledge specialized (Rolón, Chavira, Orozco, \& Soto, 2015). 


\section{MANAGEMENT , ECONOMICS AND HUMANITIES}

July 23-25 2021

Stockholm, Sweden

BPMN provides a graphical notation that expresses all aspects of processes in the form diagram, enabling the creation of end-to-end business processes. Through a Business Process Diagram and based on a flowchart technique adapted for creating model's business process operations graphs, allows for the easy development of simple and easy-to-understand diagrams.

\subsubsection{BPMN core elements}

The flowcharts developed through BPMN have several graphic elements (Figure 1) that enable the development and creation of simple and complex processes:

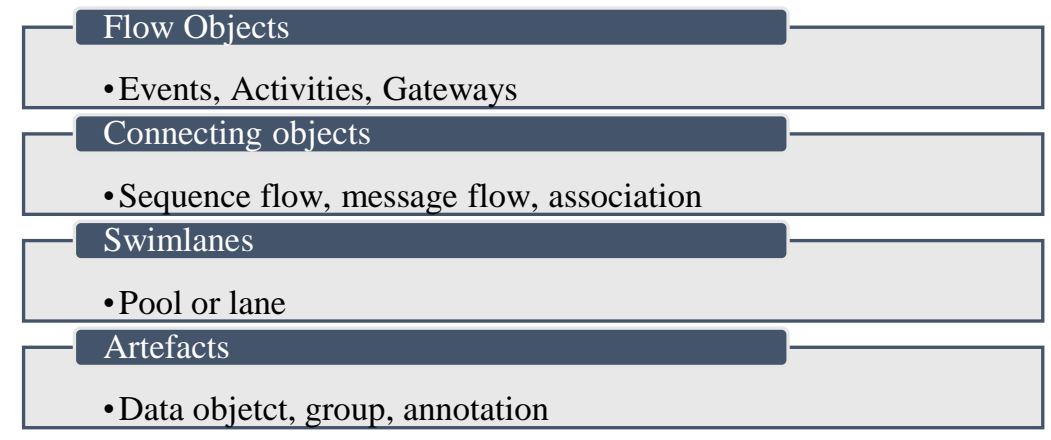

Figure 1. Graphic elements from PBMN Language.

Flow Objects - or flow objects, are main graphical elements used to represent the behaviour of the business process (Freitas \& Pereira, 2008). are divided into three groups so that modelers do not need to learn to recognize a large variety of forms (White, 2004), being the event, the activity, and the gateway (Figure 2) (Freitas AP, 2015; Gomes, 2018).

Connecting Objects - or connection objects determine the connection of objects and the order of activities during the process (Freitas \& Pereira, 2008). They are the ones that form the skeleton of the business process (White, 2004). There are three types of connectors, the Sequence Flow, Message Flow, and Association (Figure 2) (Freitas \& Pereira, 2008; Gomes, 2018).

Swimlanes - several methodologies use the concept of swimlanes as a way to organize activities and separate them into visible categories, in order to illustrate the different functions and responsibilities that each one has. They are divided into two categories, the Pool, and the Lane (Figure 2) (Freitas AP, 2015; Gomes, 2018).

Artefacts - or artefacts, are used to give additional information about the process. Any number of artifacts can be added to a diagram, being appropriate to the context. of the business process to be modelled. The BPMN defines that there are three types of artifacts, they are Data Objects, Group and Annotations (Figure 2) (Freitas A. P., 2015; Gomes, 2018). 


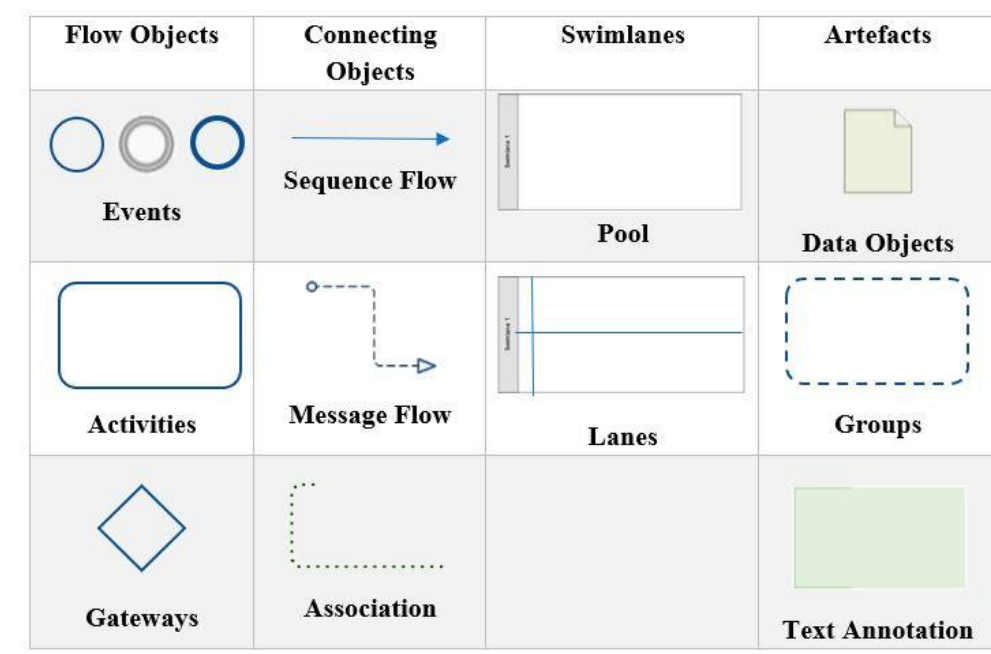

Figure 2. Groups of graphic elements from BPMN. Adapted from (Rolón, Chavira, Orozco, \& Soto, 2015)

\subsection{Hospital Processes}

Processes in hospitals are highly complex and variable, due to daily work that requires frequent reactions to both the intermediate results of diagnostic processes and unexpected medical instructions.

In addition to the complexity, these structures have a huge interdependence, that is, their services are not independent and isolated, but are interconnected, and make the organization work as a whole. The malfunction of a service interferes with the entire set of services and consequently with the final result (Gomes, 2018).

Therefore, it is extremely important that the healthcare sector maintains its current processes, not only to achieve continuous improvement in the services offered, but also as an essential part of the quality programs in which it is integrated (Rolón, Chavira, Orozco, \& Soto , 2015).

In a competitive healthcare market, it is imperative that hospitals reorganize their structure and operations to make customer service more efficient. Labour, capital, and information are critical resources: availability, correction and facilities to process information are crucial for efficient patient care (Rolón, Chavira, Orozco, \& Soto, 2015).

Organizations in the health area face several difficulties and problems in managing their numerous processes, and these problems can be divided into strategic problems, tactical problems, and operational problems. From a Business Process Management perspective, we can define a relationship with these difficulties (Figure 3), which are (Bandara, Indulska, Chong, \& Sadiq, 2007): 


\title{
MANAGEMENT , ECONOMICS AND HUMANITIES
}

\author{
July 23-25 2021 \\ Stockholm, Sweden
}

\begin{abstract}
Strategic Problems
- They relate to process-oriented, support and IT management, process organization and administration issues.

Tactical Issues

- Difficulties in process modeling, process performance measurement and methodologies.

Operational Problems

- Problems related to difficulties in the technologies that support process management..
\end{abstract}

Figura 3. Main problems in organizations.

In this type of organizations, it is common to find a manual of processes/procedures in the various services (Management, Administration, Nursing, Pathology, among others), which professionals can consult when doubts arise about a particular procedure or technique. These manuals are documents that aim to establish and standardize the main practices and procedures of a technical and organizational nature of the service (Direção-Geral da Saúde, 2014); In addition to being quite extensive, these documents are not practical in an emergency situation, and are interpretable by any type of professional.

BPM is a reliable approach to standardize processes and is one of the best practices. process management most used by organizations, which can be applied in different contexts, while the BPMN provides, through simple language, pertinent information about the process/procedure to any type of professional.

\section{Methodology}

Regarding the literature review process, this article was based on the research of articles, academic works and bibliographic documents related to the topic under study. We use search engines like Web of Science, Google Scholar, Research Gate, and platforms and repositories of higher education institutes.

Regarding to the article itself (implementation of the questionnaire and characterization results) the methodological approach used was quantitative, a technique used in projects that address research questions, data collection and analysis. The goal of this research is to obtain an answer to the question "Will it be beneficial to implement BPMN in a health institution?", through the analysis of the responses obtained in the application of a questionnaire to professionals from this type of institution. 


\section{MANAGEMENT , ECONOMICS AND HUMANITIES}

July 23-25 2021

Stockholm, Sweden

\subsection{Questionnaire characterization}

The questionnaire applied has 17 questions and was divided into 3 sections. show in Figure 4.

$$
\begin{aligned}
& \text { Service/department } \\
& \text { related questions } \\
& \text { and procedure's } \\
& \text { manual. }
\end{aligned}
$$

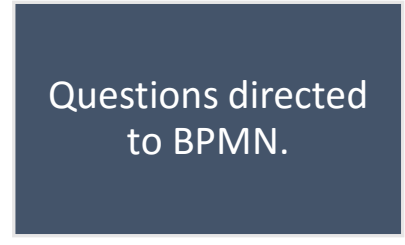

Figure 4. Questionnaire sections.

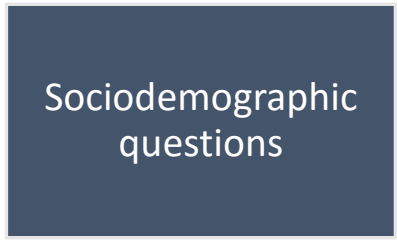

Sociodemographic questions include age, level of education, role that the respondent performs the region where it operates and the type of institution where it operates professional.

\subsection{Data collection and sample representativeness}

The questionnaire was applied online in several social networks and professional groups and had as target population all professionals who work in a health institution in National territory.

According to data from the INE (National Institute of Statistics), in 2018 there were 26879 doctors, 43166 nurses, 9795 Superior Diagnostic and Therapeutic Technicians and 6290 Superior Health Technicians and other Technicians (INE, 2020).

For the preparation of this study, a sample of professionals from the most varied areas of training, who exercised their professional activity in institutions, was considered. of health, regardless of the degree of education they had and the function they performed.

A sample of 131 professionals was defined, representing the professional fabric of the Portuguese health area. The questionnaire was implemented by Google forms, from March 29th to 07 May 2020, based on a structured questionnaire prepared in-house.

\subsection{Data treatment}

The data collected through the application of the questionnaire were subjected to a treatment statistical. In addition to the descriptive analysis procedures, statistical tests were performed on the relationship between some variables and, subsequently, a multivariate analysis based on Factor Analysis technique.

The analysis of the results was developed using the Statistical Package for Social statistical software Sciences (SPSS), version 22.0, with all statistical tests performed to a level of $5 \%$ significance.

\section{Results}

\subsection{Sample characterization}

Through an analysis of table 1 , we can verify that the sample under study consists of 131 professionals from Health Institutions, of which $32.8 \%$ are under 26 years of age. The majority of the respondents have educational qualifications at the level of a degree/CTeSP 
(being $61.1 \%$ have a degree) and perform the function of Superior Diagnostic Technician and Therapist or Senior Health Technician in the organization where they carry out their professional activity (57.3\%). The remaining functions include Department Directors, Managers, Elements of Executive Board, Engineers, Pharmacists, Physicians, and other technicians. Regarding the region of the country where they exercise, the NUTS II classification was used, being in the central region where a large part of the surveyed population is located $(71.0 \%)$. In the type of institution where they carry out their professional activity, there is a high percentage of professionals working in the National Health Service-Business Public Sector (35.9\%), and in private clinics (32.1\%).

Table 1. Sample's characterization.

\begin{tabular}{|c|c|c|c|}
\hline & & $\begin{array}{c}\mathrm{N}^{\mathrm{o}} \text { of } \\
\text { Professionals }\end{array}$ & Percentage \\
\hline \multirow[t]{5}{*}{ Ages } & Inferior to 26 Years & 43 & 32,8 \\
\hline & Between 26 e 35 Years & 41 & 31,3 \\
\hline & Between 36 e 49 Years & 35 & 26,7 \\
\hline & Superior to 50 years & 12 & 9,2 \\
\hline & Total & 131 & 100,0 \\
\hline \multirow[t]{5}{*}{ Education level } & Secondary level & 10 & 7,6 \\
\hline & Bachelor & 84 & 64,1 \\
\hline & After Graduation & 20 & 15,3 \\
\hline & Master/ MBA or Superior & 17 & 13,0 \\
\hline & Total & 131 & 100,0 \\
\hline \multirow[t]{6}{*}{ Role } & $\begin{array}{l}\text { Management/ Administration/ } \\
\text { Executive Board }\end{array}$ & 14 & 10,7 \\
\hline & Superior Technician & 75 & 57,3 \\
\hline & Nurse & 25 & 19,1 \\
\hline & Doctor & 5 & 3,8 \\
\hline & Other & 12 & 9,2 \\
\hline & Total & 131 & 100,0 \\
\hline \multirow{4}{*}{ Region where they work } & Centre Region & 93 & $\overline{71,0}$ \\
\hline & Lisbon Area & 20 & 15,3 \\
\hline & Other regions & 18 & 13.7 \\
\hline & Total & 100 & 100,0 \\
\hline \multirow{4}{*}{$\begin{array}{l}\text { Type of Institution where } \\
\text { they work }\end{array}$} & SNS- Public Sector & 47 & 35,9 \\
\hline & Private Clinics & 42 & 32,1 \\
\hline & Other Institutions & 42 & 32,1 \\
\hline & Total & 131 & 100,0 \\
\hline
\end{tabular}




\section{MANAGEMENT , ECONOMICS AND HUMANITIES}

July 23-25 2021

Stockholm, Sweden

\subsection{The importance of the processes in the institution and department}

It was intended to know the importance that professionals who exercise in institutions of health, give to the processes that are developed in your institution and department. That way, a set of 9 statements were gathered, Table 2, which assess the agreement of professionals regarding the importance of knowledge of the processes carried out, the existence of a manual procedures and the confidence and ease with which professionals consult it (if any).

We can thus divide the statements into two categories: the first one relating to knowledge of the processes and their importance; and a second directed to the procedures manual present in the departments/services.

On average, respondents attribute higher levels of agreement to statements "I would like to better understand the processes carried out in the institution where I work" and "I think It is important that all elements of the institution where I work have a general knowledge. on the processes carried out in it.", the latter reaching the highest average of 4.49 , and a lower standard deviation of 0.826 indicating a high degree of agreement by of respondents (Table 2).

In the statements directed to the procedure's manual, in the statement "There is a procedures manual relating to all procedures/processes that occur in my department/service.", we observe the highest standard deviation value of all affirmations, meaning that the respondents were not unanimous in their answers, that is, there are departments/services with and without manual of procedures. The lowest average is found associated with the statement "I find it easy and quick to consult the procedures manual of my service/department", with a value of 3.26 (Table 2).

Table 2. Degree of Agreement, through Likert Scale, with the exposed statements.

\begin{tabular}{|c|c|c|c|c|c|}
\hline & $\mathrm{N}$ & Mín. & Máx. & Mean & $\begin{array}{c}\text { Stand. } \\
\text { Deviation }\end{array}$ \\
\hline $\begin{array}{l}\text { For each statement that follows, select the grade } \\
\text { that best describes your opinion. } \\
\text { 1. I am aware of all processes/ procedures carried out } \\
\text { in my department/service. }\end{array}$ & 131 & 1 & 5 & 3,69 & 1,089 \\
\hline $\begin{array}{l}\text { 2. I have general knowledge of the processes carried } \\
\text { out in the institution where I work. }\end{array}$ & 131 & 1 & 5 & 3,74 & ,908 \\
\hline $\begin{array}{l}\text { 3. I would like to better understand the processes } \\
\text { carried out in the institution where I work. }\end{array}$ & 131 & 1 & 5 & 4,01 & ,846 \\
\hline $\begin{array}{l}\text { 4. I think it is important that all elements of the } \\
\text { institution where I work have a general knowledge } \\
\text { of the processes carried out in the institution. }\end{array}$ & 131 & 1 & 5 & 4,49 & ,826 \\
\hline $\begin{array}{l}\text { 5. There is a procedures manual relating to all } \\
\text { procedures/processes that take place in my } \\
\text { department/service. }\end{array}$ & 131 & 1 & 5 & 3,66 & 1,214 \\
\hline
\end{tabular}




\section{$11^{\text {th }}$ INTERNATIONAL CONFERENCE ON}

MANAGEMENT , ECONOMICS AND HUMANITIES

July 23-25 2021

Stockholm, Sweden

6. In case of doubt, I can consult the manual mentioned above.

7. It is easy to understand the processes performed in my department when I refer to the manual.

8. I feel confident with the procedure's manual in my service/department.

9. I find it easy and quick to consult the procedures manual of my service/department.

\begin{tabular}{|r|r|r|r|r|}
131 & 1 & 5 & 3,65 & 1,208 \\
131 & 1 & 5 & 3,35 & 1,123 \\
131 & 1 & 5 & 3,34 & 1,101 \\
131 & 1 & 5 & $\mathbf{3 , 2 6}$ & 1,134 \\
& & & & \\
\hline
\end{tabular}

\subsection{BPMN Implementation}

One of the direct questions asked to respondents was "Do you think it is advantageous to implement a method/notation (BPMN) that defines and characterizes the processes carried out in the health unit where you work?". In (Figure 6) the professionals' answers are exposed, with $72.52 \%$ of positive answers and only $3.05 \%$ of negative answers. We can thus conclude that most professionals find it advantageous to implement the BPMN in the institution where they work.
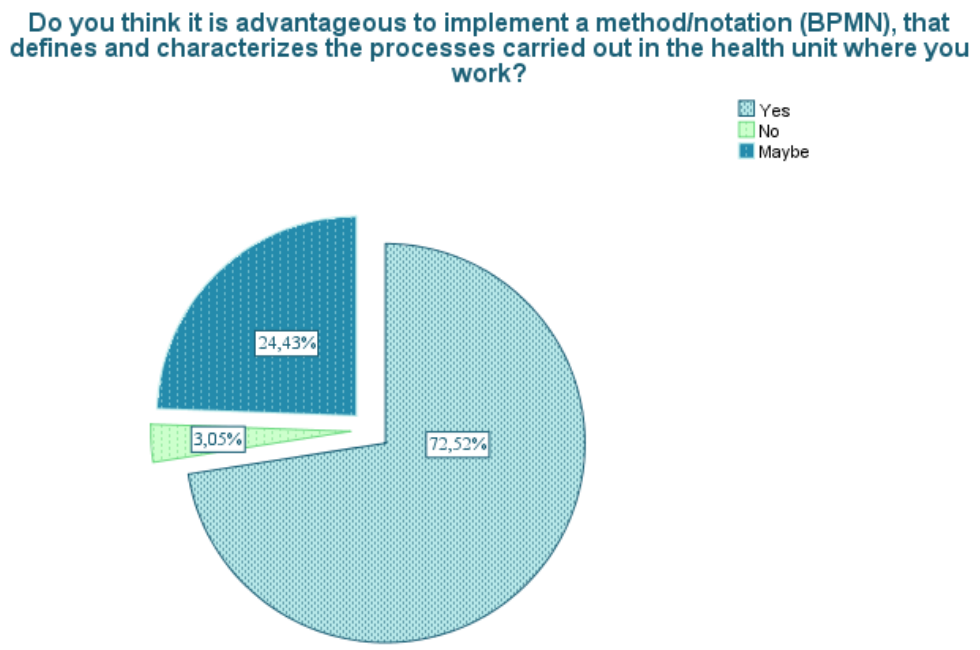

Figure 5. Answers to the question "Do you think it is advantageous to implement a method/notation (BPMN), that defines and characterizes the processes carried out in the health unit where you work?"

\subsection{BPMN Knowledge}

In order to investigate the percentage of professionals who had knowledge of BPMN and the level of this knowledge, two questions were applied to the respondents, namely "Do you have knowledge of BPMN" and "What is your level of knowledge of BPMN (Business Process Modeling Notation) ) ?". The answers are shown in Figure 6 and Figure 7. 


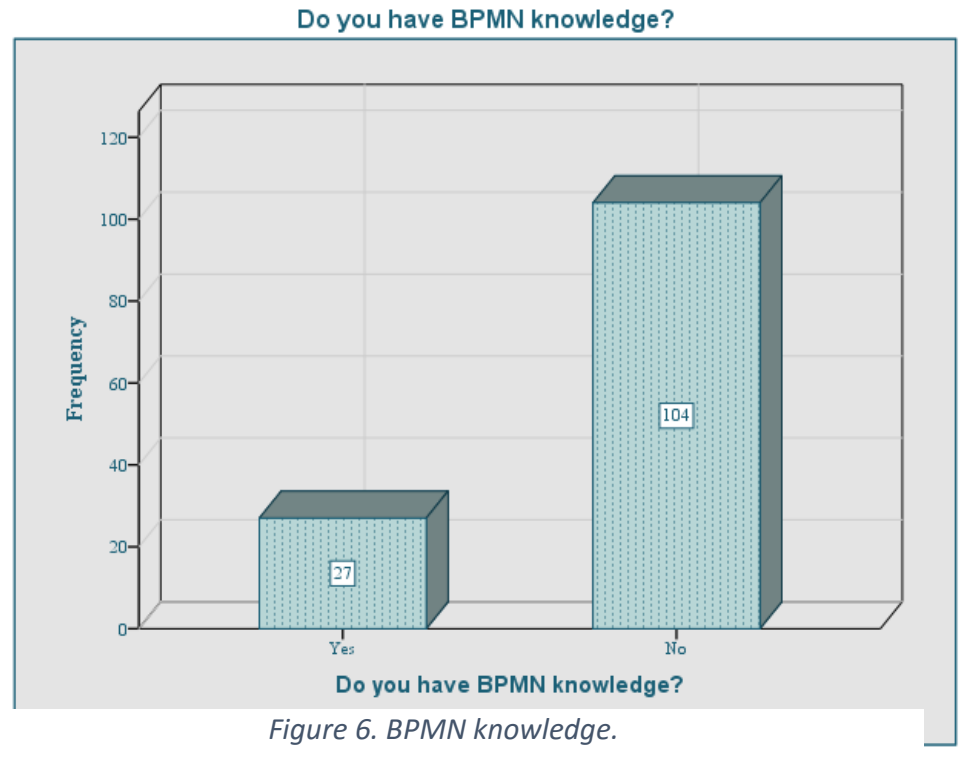

Regarding the first question, we obtained 27 positive responses (20.6\%) and 104 negative responses (70.4\%), revealing that the vast majority of professionals do not have any knowledge of BPMN. The 27 professionals who responded positively were asked to indicate the degree of knowledge of this notation, using a Likert scale. On this scale, 1 represents "Little knowledge" and 5 "Advanced knowledge".

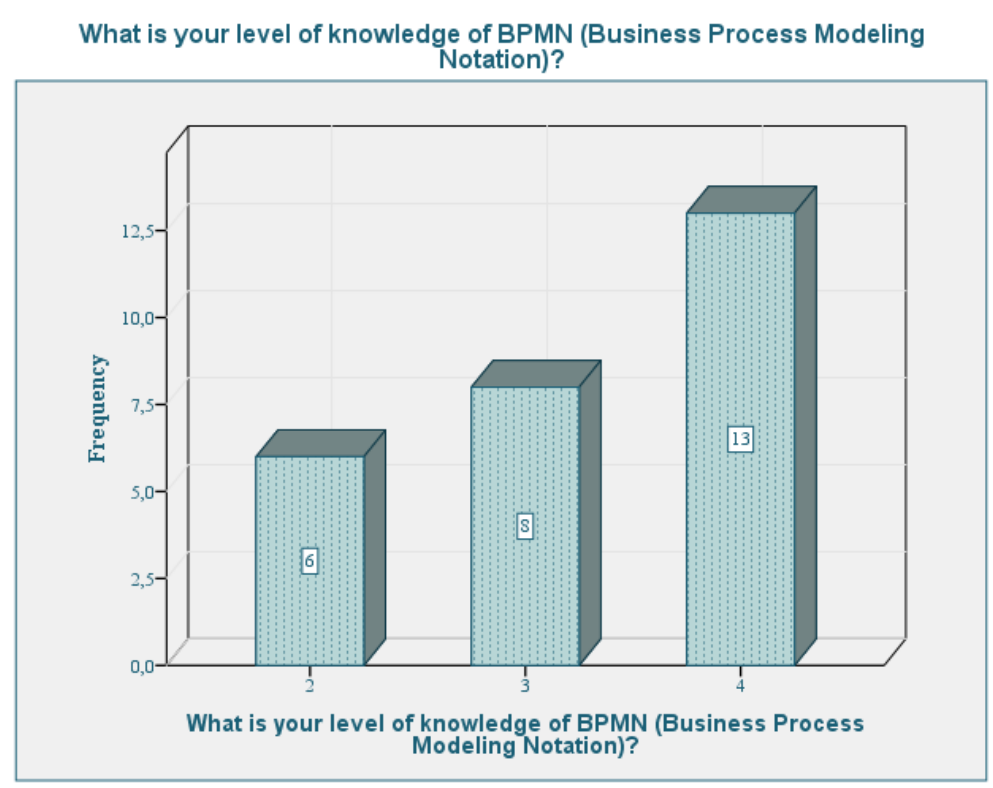

Figura 7. Level of knowledge of BPMN from the professionals inquired.

The average degree of knowledge of professionals was around 3.26, with a standard deviation of 0.813 . 


\section{$11^{\text {th }}$ INTERNATIONAL CONFERENCE ON}

MANAGEMENT , ECONOMICS AND HUMANITIES

July 23-25 2021

Stockholm, Sweden

\subsection{Knowledge of BPMN and Role performed}

Fisher's test identified a statistically significant association between the variables "Indicate the role you play in the organization where you perform your professional activity" and "Have knowledge of BPMN" $(p<0.01)$. In particular, it is observed that professionals who perform functions in the area of administration/management/direction are the ones who have the most knowledge of BPMN (50\%), while only $20 \%$ of senior technicians, $10 \%$ of nurses and doctors and 16,7\% of other roles (which include pharmacists, engineers, and other technicians) are aware of this notation. It should be noted that none of the physicians surveyed has knowledge of BPMN.

As BPMN is a notation used mainly in business management areas (Fernández, Fernandéz, \& García, 2019), it is expected that functions in the areas of management/administration/direction have this knowledge. However, we observed that, regardless of function, there are other professionals with this knowledge (Figure 8).

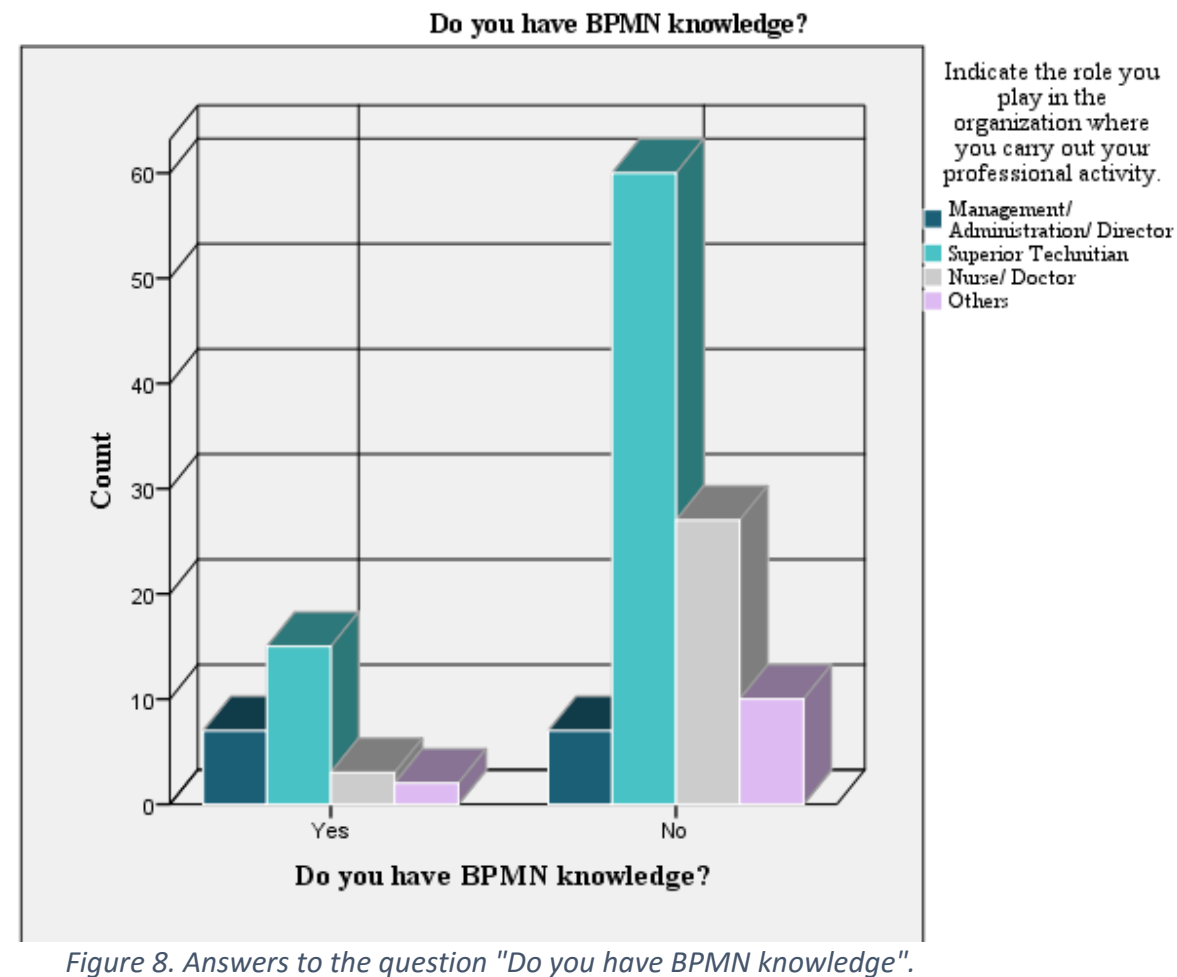

\subsubsection{Procedure's manual and knowledge of processes}

Spearman's correlation test allowed identifying the existence of a significant correlation $(p<0.01)$ between the questions "I find it easy and fast to consult the procedures manual of my service/department" vs. "I feel confident with the existing procedures manual in my service/department", with a correlation coefficient of 0.895 (coefficient varies between -1 and +1 ), indicating the existence of a strong correlation between the two variables. 


\section{$11^{\text {th }}$ INTERNATIONAL CONFERENCE ON}

MANAGEMENT , ECONOMICS AND HUMANITIES

July 23-25 2021

Stockholm, Sweden

When researching the existence of statistically significant differences with regard to General knowledge of processes in the institution where the professional works for the various functions performed, the Kruskal-Wallis test showed that there is an effect of the function that the professional performs on the general knowledge of the processes in the institution where he works $(\mathrm{p}=0.044)$.

Through the graph in Figure 9, we can see that the remaining "Other" functions have a different perception regarding the knowledge they have about the processes of the institution where they work (They have more knowledge), while the "Doctor" function has less knowledge.

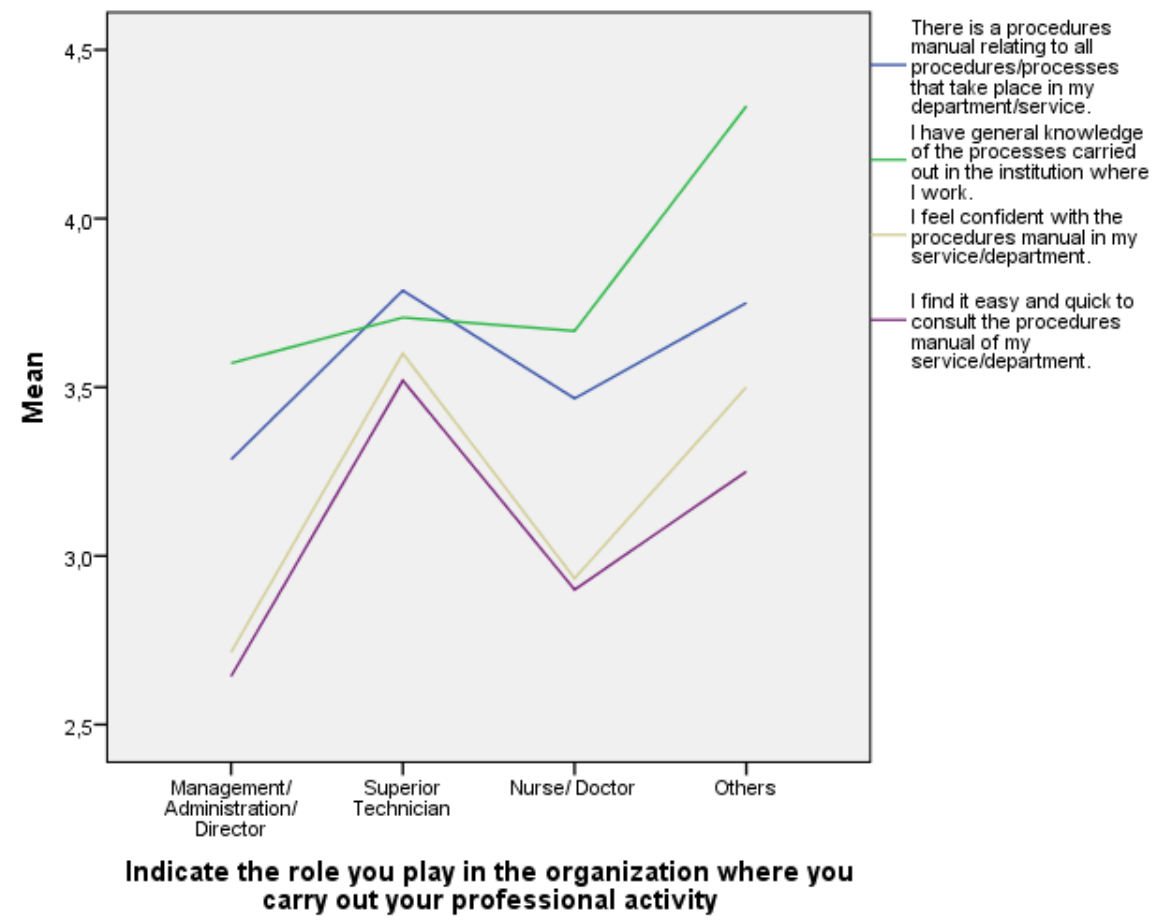

Figura 9. Mean from the answers to the questions considered important when applied the Kruskal Wallis Test, relating them to the role the professional has in the institution.

When we relate the professional's role to the knowledge of the existence of a procedure manual in the service/department, where he performs his function, we verify that the function has an effect on the knowledge of the existence of a manual in the service (Figure 10). 


\section{$11^{\text {th }}$ INTERNATIONAL CONFERENCE ON}

MANAGEMENT , ECONOMICS AND HUMANITIES

July 23-25 2021

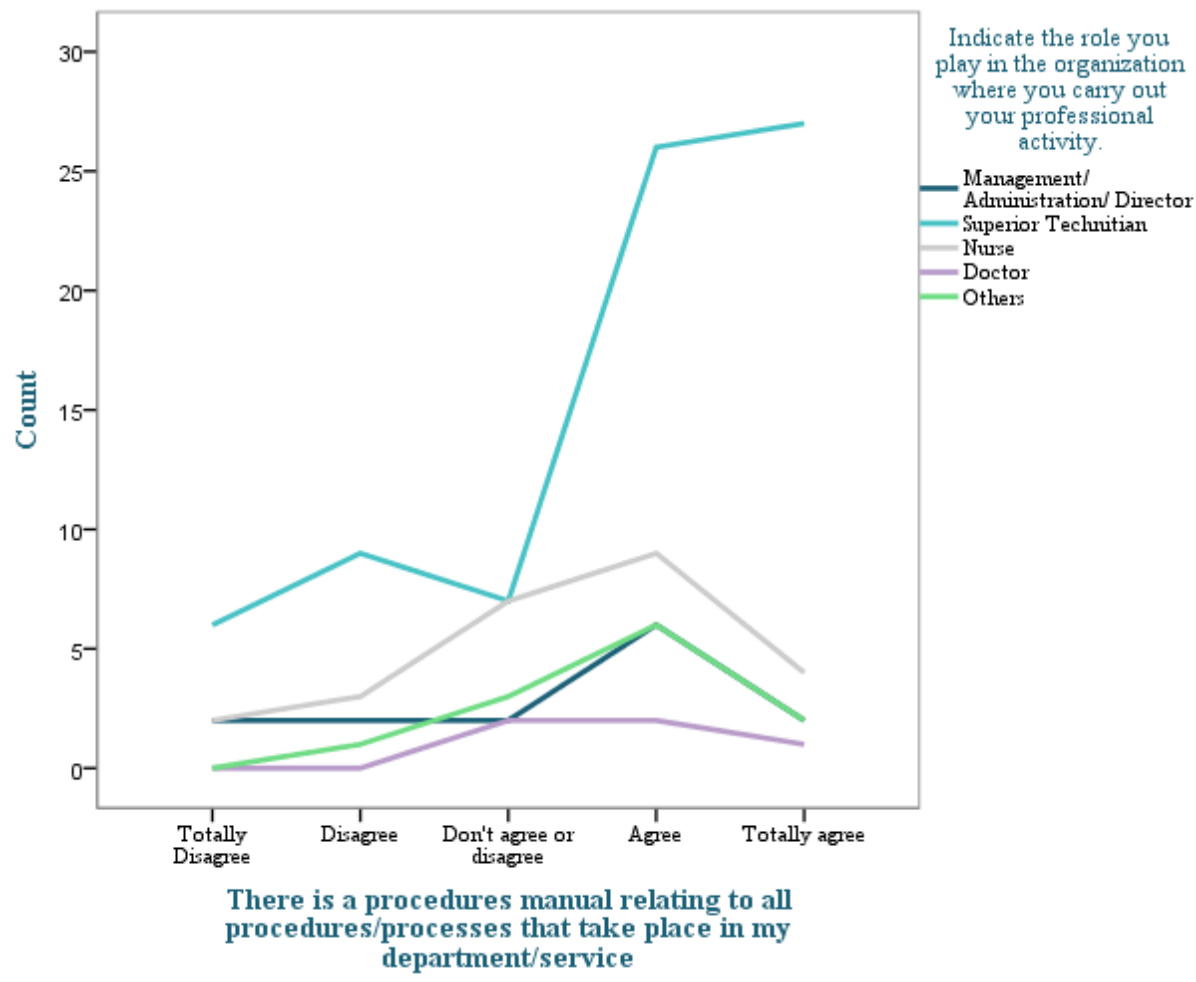

Figura 10. Answers to the question "There is a procedure's manual (...) in my department" according to the role the professional has.

We realized that Superior Technicians, professionals who perform functions in the area of Management, Nurses and other professionals, responded in their vast majority that they agreed with the statement "There is a manual of procedures relating to all procedures/processes that occur in my department/ service", leaving only the doctors with a greater number of responses, not only in the "I agree" option, but also in the "I neither agree nor disagree" option. There is also a low number of professionals answering, "Strongly Disagree" and "Disagree". Therefore, we conclude that regardless of function, professionals, for the most part, have a manual of procedures in their service.

When applying the Kruskal-Wallis test to the relationship between the function that the professional performs and the confidence that the professional has in the procedure's manual in their department/service, we conclude that the first has an effect on the second, obtaining a $\mathrm{p}=0.004$.

Through the analysis of the graph in Figure 9, we realize that Senior Technicians and "Others" are the ones who feel more confident with the procedures manual present in the service, unlike professionals in the area of management/Administration/Direction and Physicians, who have less confidence in the same documents.

When related to the professional's function and the perception of the same regarding the ease and speed of consulting the procedures manual, we verified an effect of the first variable on the second $(\mathrm{p}=0.011)$. Through the analysis of the graph in Figure 9, we observe that, as in the previous question, the "Senior Technicians" and "Other" professionals find it 
easy and quick to consult the manual, while professionals in the area of "Management/Administration/Direction" and "Doctors", disagree with the statement.

\subsection{Factor analysis}

Factor analysis allows the identification of latent, not directly observable, variables based on the grouping of observed variables. The observed correlations between the variables result from the fact that they share common factors (correlated variables). As the questionnaire used in the study was designed in-house, we carried out an exploratory factor analysis, which allows us to reduce the number of variables.

In this sense, the Likert scale items (Table 2) were subjected to a Factor Analysis, obtaining a KMO of 0.819 and a p-value $<0.001$ associated with the Bartlett Test, indicating that the Factor Analysis techniques are suitable to the sample under analysis.

The Principal Component Analysis was used to extract the axes and to determine the number of axes to retain, Cattell's Scree Plot was used. The three retained axes explain $80.7 \%$ of the total variance. After the Varimax rotation, the distribution of items according to the factors presented in Table 3 was obtained. In order to facilitate the interpretation, factor loadings below 0.3 were removed.

\section{Table 3. Rotating component matrix. Self-elaboration. Extraction Method: Principal Component Analysis; Rotation Method: Varimax with Kaiser Normality.}

Rotating component matrix

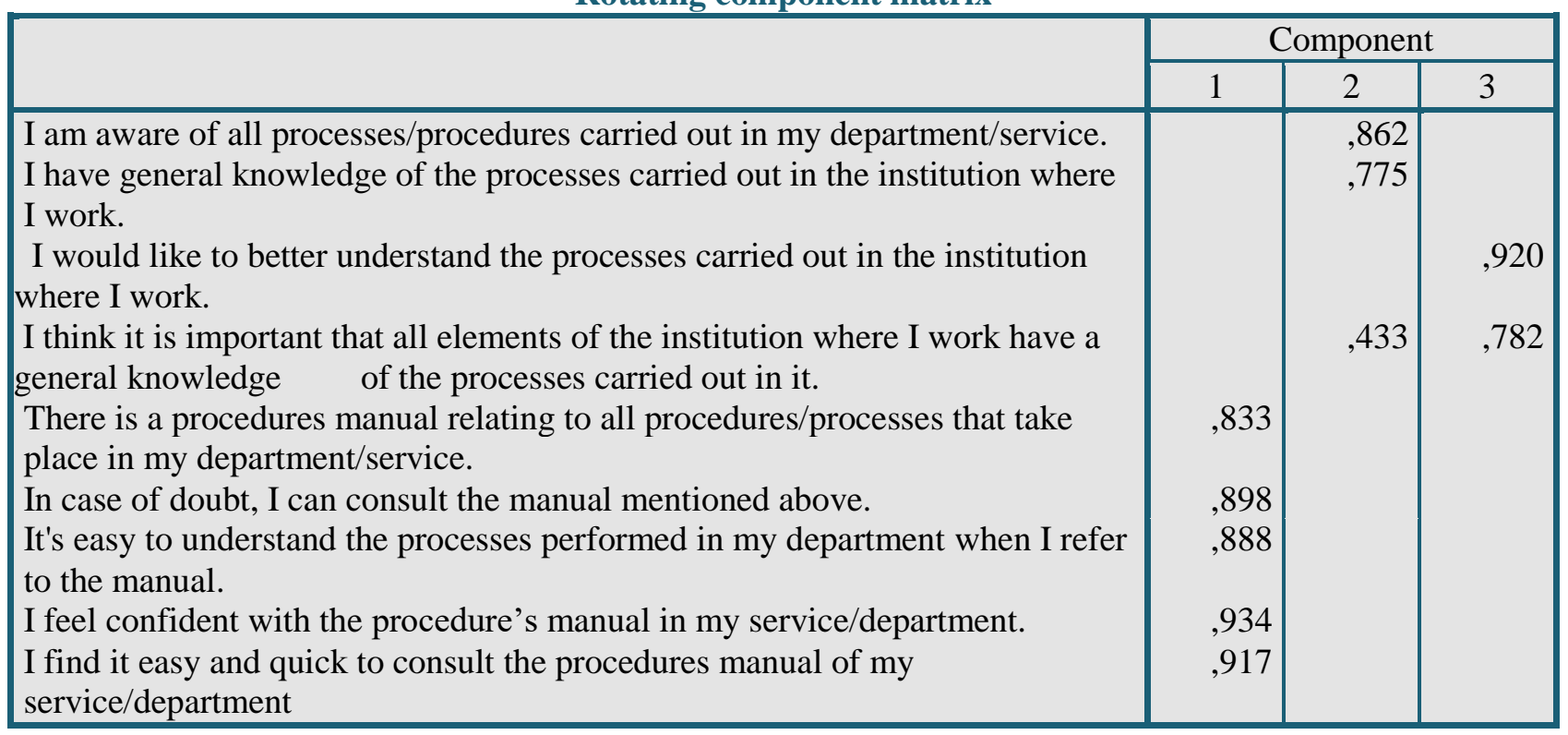

The factorial structure obtained shows that Factor 1 gathers the items related to the procedure's manual, Factor 2 is related to personal knowledge of the processes, and Factor 3 concentrates information on the importance of general knowledge of the processes. 


\section{$11^{\text {th }}$ INTERNATIONAL CONFERENCE ON}

MANAGEMENT , ECONOMICS AND HUMANITIES

July 23-25 2021

Stockholm, Sweden

As a measure of internal consistency, Cronbach's Alpha by factors was used (Table 4), obtaining satisfactory levels ranging between 0.677 (Importance of general knowledge of the processes) and 0.947 (Procedures Manual); and Cronbach's Alpha for the full scale of 0.857.

Table 4. Cronbach's Alpha

\begin{tabular}{|l|c|c|}
\hline \multicolumn{1}{|c|}{ Factor/ Scale } & $\begin{array}{c}\mathbf{N}^{\mathbf{o}} \text { of } \\
\text { items }\end{array}$ & Cronbach's Alpha \\
\hline 1. Procedure's Manual & 5 & 0,947 \\
\hline 2. Personal knowledge of the processes & 2 & 0,646 \\
\hline 3. Importance of general knowledge of the & 2 & 0,677 \\
\hline $\begin{array}{l}\text { processes } \\
\text { 4. } \begin{array}{l}\text { Complete scale } \\
\hline\end{array}\end{array}$ & 9 & 0,857 \\
\hline
\end{tabular}

Next, we present the descriptions (minimum, maximum, mean and standard deviation) for the retained factors (Table 5):

Table 5. Descriptions of Retained Factors. Self-elaboration.

\begin{tabular}{|l|c|c|c|c|c|}
\hline \multicolumn{1}{|c|}{ Factor } & N & Mín. & Máx. & Mean & $\begin{array}{c}\text { Standard } \\
\text { Deviation }\end{array}$ \\
\hline 1. Procedure's Manual & 131 & 1,00 & 5,00 & 3,4519 & 1,050 \\
\hline $\begin{array}{l}\text { 2. Personal knowledge of the } \\
\text { processes }\end{array}$ & 131 & 1,00 & 5,00 & 3,7137 & 0,86164 \\
\hline $\begin{array}{l}\text { Importance of general knowledge } \\
\text { of the processes }\end{array}$ & 131 & 1,00 & 5,00 & 4,2481 & 0,727 \\
\hline
\end{tabular}

We can verify, regarding the retained factors, that the highest average (4.2481) belongs to Factor 3 (which includes questions about the importance of more generalized knowledge of the processes), indicating that the interviewed professionals give a higher score, and consequently, more importance, to questions related to the general knowledge of the processes in the institution where they work. The standard deviation of this factor (0.727) indicates a concentration of similar responses by respondents, compared to the other factors, which have higher standard deviations.

Although all factors have relatively high means, the lowest mean (3.4519) belongs to Factor 1 (includes the questions that address the procedures manual), which, together with the standard deviation (1.050), refer to a high dispersion in the responses obtained, indicating that there are professionals with and without manuals of procedures in the services where they perform their functions, and that consequently they may or may not be able to consult these same documents.

Regarding Factor 2 (Personal knowledge of the processes), it encompasses the most directed questions for the knowledge of the processes at the personal level of each professional. It has a mean of 3.7137 and a standard deviation of 0.86164 . 
MANAGEMENT, ECONOMICS AND HUMANITIES

July 23-25 2021

Stockholm, Sweden

\section{Discussion and Conclusion}

The aim of this article was directed to the study of the need to implement a BPMN system, in a health institution, through the analysis of data obtained when professionals who work in this type of institution were asked. There are some points in the results of this article that deserve to be discussed in light of the literature review.

In a first approach, Business Process Management is mostly used in management and business areas, as reported by Fernández (2019), and it is therefore natural that most respondents do not have any knowledge of BPM or BPMN.

Regarding the importance of processes in the institution and services, we quickly understood that health professionals not only would like to better understand the processes (of their service and institution), but they also think that this knowledge would be very important, following and emphasizing the point of view of Gomes (2018), who argues that "the basis of an organization is the way its processes are managed".

With regard to the procedure manuals present in various health services, low averages were presented, especially when related to the function [Kruskal-Wallis Test], as is the case with Physicians and Professionals in the area of Management/Administration/Direction that they feel less confident with the existing procedure manual, and do not find it easy and quick to consult.

The same is supported by the answers to the question "Do you find it advantageous to implement a method/notation that defines and characterizes the processes (...)?"; although only $20.6 \%$ of professionals have some kind of knowledge of BPMN, $72.5 \%$ responded that the implementation of such a method was advantageous, highlighting the dissatisfaction of health professionals.

The fact that healthcare organizations do not have clear and formalized processes leads to inefficiencies across the entire organization. Thus, it is important to know all the existing processes in this type of institutions and make the knowledge around them accessible to any professional, so that they are prepared to provide their service, and so that in case of doubt, can access pertinent, clear, and objective information about these same processes (Muller \& Solti, 2011), reducing errors and failures, both technical and human.

The use of BPM (Business Process Management) was thus considered, a discipline aimed at the business processes of institutions, but which could be applied to other areas, namely the health area, as described by Rolón, Chavira, Orozco, and Soto, (2015) and Fernández (2019).

Regarding the limitations of the study, we highlight the fact that $57.3 \%$ of respondents were Senior Technicians, the non-existence of respondents in the autonomous region of Madeira, and that the number of respondents could be higher. Thus, there is no balanced sample, namely in terms of the functions performed by professionals, so in future studies, we call not only for an increase in the number of respondents in general, but also for the number of respondents in the other functions performed in this type of institutions (namely doctors and professionals in the areas of management), in order to obtain a study that represents the Portuguese reality in the area of health. 
MANAGEMENT , ECONOMICS AND HUMANITIES

July 23-25 2021

\author{
Stockholm, Sweden
}

In short, we found that professionals, in general, attach a high degree of importance to the processes and procedures carried out in the institution and in the service where they work, but they do not feel confident with the procedures manual they have. They also consider that the implementation of the BPMN would be an asset to define and characterize the processes in an institution.

\title{
References
}

Bandara, W., Indulska, M., Chong, S., \& Sadiq, S. (2007). Major Issues in Business Process Management: An Expert Perspective. ECIS, 1240- 1251. Obtido em 03 de Maio de 2020, de https://eprints.qut.edu.au/14345/

Direção-Geral da Saúde. (31 de Dezembro de 2014). Manual de Procedimentos no âmbito da Saúde do Trabalho. Informação Técnica nº/2014. Direção-Geral da Saúde.

Fernández, A. D., Fernandéz, D. R., \& García, Y. S. (4 de Outubro de 2019). Business Process Management for optimizind clinical processes: A systematic literature review. Health Informatics Journal, 1-16. doi:10.1177/1460458219877092

Freitas, A. P. (Outubro de 2015). A utilização da Linguagem BPMN em contex tos de simulação de processos. Tese de Mestrado em Engenharia e Gestão de Sistemas de Informação. Universidade do Minho- Escola de Engenharia. Obtido em 24 de Maio de 2020, de http://repositorium.sdum.uminho.pt/handle/1822/41878

Freitas, A., \& Pereira, J. (2008). Process Simulation Support in BPM Tools: The Case of BPMN. Proceedings of 2100 Projects Association Joint Conferences, 1-9. Obtido em 11 de Maio de 2020, de https://repositorium.sdum.uminho.pt/handle/1822/39192?locale=en

Gomes, J. C. (Outubro de 2018). BPM em processos hospitalares usando BPMN. Dissertação de Mestrado- Mestrado Integrado em Engenharia e Gestão e Sistemas de Informação. Minho, Portugal: Universidade do Minho, Escola de Engenharia. Obtido em 03 de Junho de 2020, de http://repositorium.sdum.uminho.pt/bitstream/1822/59125/1/Disserta\%C3\%A7\%C3\% A3o\%2Ba72357\%2BJo\%C3\%A3o\%2BGomes.pdf

Instituto Nacional de Estatística. (2020). Estatísticas da Saúde - 2018. Lisboa: Instituto Nacional de Estatística, I.P. Obtido em 18 de Maio de 2020, de Instituto Nacional de EstatísticaStatistics Portugal: https://www.ine.pt/xportal/xmain?xpid=INE\&xpgid=ine_publicacoes\&PUBLICACO ESpub_boui=257793024\&PUBLICACOESmodo=2

Júnior, M. F., Rocha, F., \& Cunha, M. (2013). Modelagem de Processos de Negócio de Saúde utilizando a notação BPMN: O caso do Samu 192 do Estado de Alagoas. Congresso de Pesquisa e Inovação da Rede Norte Nordeste de Educação Tecnológica. Salvador: Connepi. Obtido em 15 de Maio de 2020, de https://www.researchgate.net/publication/284087051_Modelagem_de_Processos_de_ 
Negocio_de_Saude_Utilizando_a_Notacao_BPMN_O_Caso_do_Samu_192_do_Esta do_de_Alagoas

Kim, C.-H., Dong-Soon Yim, \& Weston, R. (2001). An integrated use of IDEF0, IDEF3 and Petri net methods in support of business process modelling. Journal of Process Mechanical Engineering, 317-329. doi:10.1243/0954408011530523

Lee, R., \& Dale, B. (1998). Business process management: a review and evaluation. Business Management Journal. Obtido em 03 de Maio de 2020, de https://www.emerald.com/insight/content/doi/10.1108/14637159810224322/full/html

Lucis Software Inc. (2020). What is Business Process Modeling Notation. Obtido em 11 de Maio de 2020, de Lucidchart: https://www.lucidchart.com/pages/bpmn\#section_2

Muller, R., \& Solti, A. (2011). BPMN for heathcare processes. 3rd Central-European Workshop on Services and their Composition, Services und ihre Komposition. Germany: Proceedings. Obtido em 17 de Junho de 2020, de https://www.researchgate.net/publication/220805177_BPMN_for_healthcare_process es

Rolón, E., Chavira, G., Orozco, J., \& Soto, J. P. (2015). Towards a framework for evaluating usability of business process models with BPMN in health sector. Procedia Manufacturing, 5603-5610.

Siau, K. (2010). An Analysis of Unified Modeling Language (UML) Graphical Constructs Based on BWW Ontology. Journal of Database Management. Obtido em 14 de Junho de 2020 , de https://www.researchgate.net/publication/242486128_An_Analysis_of_Unified_Mod eling_Language_UML_Graphical_Constructs_Based_on_BWW_Ontology

Silva, F. G., \& Soares, M. S. (2016). Modelagem de Processos de Negócios usando BPMN para Desenvolvimento de um Prontuário Eletrônico de Pacientes. Journal of Health Informatics, 178-183. doi:2175-4411

Stemerding, A., \& Dijk, A. v. (2005). Business Process Modeling-Basic guidelines and tips. Delotte.

van der Aalst, W., ter Hofstede, A. H., \& Weske, M. (2003). Business Process Management: A Survey. Springer-Verlag Berlin Heidelberg, 1-12. doi:10.1007/3-540-44895-0_1

White, S. a. (2004). Introduction to BPMN. BPTrends, 1-11. Obtido em 22 de Maio de 2020, de https://www.omg.org/bpmn/Documents/Introduction_to_BPMN.pdf 